\title{
AN IMPROVED METHOD FOR THE DETERMINATION OF HISTAMINE RELEASE IN MAN: ITS APPLICATION IN STUDIES WITH PROPANIDID AND THIOPENTONE*
}

\author{
W. LORENZ**, A. DOENICKE, R. MEYER, H.J. REIMANN, J. KUSCHE, \\ H. BARTH, H. GEESING, M. HUTZEL and B. WEISSENBACHER \\ Institute of Clinical Chemistry and Clinical Biochemistry, and Division of Anesthesiology, Surgery Outpatient Clinic, \\ University of Munich and Division of Experimental Surgery and Pathological Biochemistry. \\ Surgery Clinic of University of Marburg/Lahn, W. Germany
}

Received 22 September 1971

Accepted 28 March 1972

W. LORENZ, A. DOENICKE, R. MEYER, H.J. REIMANN, J. KUSCHE, H. BARTH, H. GEESING, M. HUTZEL and B. WEISSENBACHER, An improved method for the determination of histamine release in man: its application in studies with propanidid and thiopentone, European J. Pharmacol. 19 (1972) 180-190.

Histamine release by propanidid and thiopentone was demonstrated with the use of a highly sensitive and specitic method for determining histamine in human plasma. 5 min after i.v. administration of propanidid and 3 min after thiopentone, the plasma histamine level was increased by 350 and $420 \%$ respectively. In whole blood, histamine release could be demonstrated only when the basophil content remained constant. This was the case in about $50 \%$ of test persons after injection of propanidid, but not after administration of thiopentone where the basophil content decreased in all probands by about $35 \%$. The increase of the histamine concentration in plasma was $3 \mathrm{ng} / \mathrm{ml}$ and in whole blood, $24 \mathrm{ng} / \mathrm{ml}$. Half-maximum gastric acid secretion was elicited by injection of propanidid and thiopentone. It was increased by very rapid application of propanidid and diminished by premedication with atropine by about $30 \%$. The changes in plasma histamine and gastric secretion were parallel over 30 min, whereas tachycardia and peripheral arterial hypotension lasted for only $3-4 \mathrm{~min}$.

During i.v. infusion of histamine a correlation could be shown between the doses infused, $(15-90 \mathrm{ng} / \mathrm{kg}) / \mathrm{min}$, and the elevation of the plasma histamine concentration. $3 \mathrm{ng} / \mathrm{ml}$ plasma were measured at a dose of $(45 \mathrm{ng} / \mathrm{kg}) / \mathrm{min}$, which induced a half-maximum gastric secretion, but was without effect on blood pressure and heart rate. It is concluded that only the increase of plasma histamine concentration, not that of whole blood, represented the release of free, pharmacologically active histamine. In normal test persons, histamine release by propanidid and thiopentone is without significant clinical consequences, but it is important in anaphylactoid incidents occurring during anesthesia with these substances.

Plasma histamine Histamine release Propanidid Thiopentone

\section{INTRODUCTION}

Histamine release by drugs used before and during anesthetic administration in man and animals has

* Members of SFB 37 'Restitution und Substitution innerer Organe' of Deutsche Forschungsgemeinschaft.

** Requests for reprints should be send to Professor Dr. W. Lorenz, Division of Experimental Surgery and Pathological Biochemistry, Surgery Clinic of University Marburg/Lahn, Robert-Koch-Strasze 8. been proven by numerous authors, since its first observation by Alam et al. (1939) in the skeletal muscle of dogs (for reviews see Paton, 1956, 1957, 1959; Murphy, 1962; Rotschild, 1966; Lorenz and Werle, 1971). Sometimes direct methods have been used, when histamine itself was measured in body fluids or in tissues. More often, however, indirect methods have been employed when clinical symptoms and changes of pharmacologically measurable parameters, such as gastric secretion, decrease in peripheral arte- 
rial blood pressure, tachycardia and increase in bronchial resistance, were concluded to be a result of histamine release. These symptoms and measurable reactions are, however, specific for histamine only in a limited sense.

Direct proof of histamine release by drugs administered before and during anesthesia is extremely difficult to obtain in humans, despite availability of simple specific assay methods for determination of histamine in whole blood, because an increase of free, pharmacologically active plasma histamine is masked by the nearly 100 -fold higher concen trations of histamine stored in the blood within the basophil granulocy tes (Code, 1952; Lorenz and Werle, 1971).

The histamine content of human plasma is so low, that its determination has in the past been especially difficult (Adam et al., 1957; Graham et al., 1968). However, with an improved, highly sensitive and specific method for plasma histamine determination (Lorenz et al., 1970a; Lorenz et al., 1972) it has been possible, to show histamine release in man by 2 anesthetic drugs often used in European clinics: propanidid and thiopentone. Recent information of anaphylactoid incidents during anesthesia with both substances led us to this investigation. To demonstrate that the increased concentration of plasma histamine was actually free, pharmacologically active histamine, gastric acid secretion, heart or pulse rate and peripheral arterial blood pressure were also measured. To determine whether histamine release in man can be demonstrated by histamine assay of whole blood, the histamine concentration and the density of basophilic granulocytes in whole blood, in which histamine in humans may be localized almost exclusively, were also measured.

\section{MATERIALS AND METHODS}

\subsection{Materials}

\subsubsection{Drugs}

Propanidid (Bayer, Leverkusen): a colloidal solution consisting of propanidid (3-methoxy-4-(N,N-diethylcarbamoylmethoxy)-phenylacetic acid-n-propyl ester), Micellophor (20\%), $\mathrm{NaCl}$ and phosphate salts, as well as water, prepared according to instructions of the company (Wirth and Hofmeister, 1965; Scholtan and Lie, 1966).

Micellophor ${ }^{\circledR}$ (Bayer Leverkusen): a colloidal solution consisting of $20 \%$ Micellophor $=$ ORPE (oleum ricini polyoxyethylate Elberfeld), $\mathrm{NaCl}$ and phosphate salts, as well as water, as stated by the manufacturer. Micellophor contains the hydrophobic components of Cremophor $\mathrm{EL}^{\circledR}$ (BASF, Ludwigshafen), which was used in diluted form until 1967 as a solvent for propanidid (Doenicke et al., 1968), and consists of ricinoleic acid, polyglycol esters and glycerol, polyglycol ethers.

Thiopentone (Penthotal ${ }^{\circledR}$, Abbott, Ingelheim).

Atropinum sulfuricum (from University's pharmacy).

Antazoline (Antistin ${ }^{\circledR}$, Ciba, Basel).

\subsubsection{Reagents}

Histamine dihydrochloride puriss. (Fluka, Buchs), o-phtaldialdehyde puriss. p.a. (Fluka, Buchs) (recrystallized from petrol ether p.a., b.p. $40-60^{\circ}$ ), methanol, $n$-heptane, inorganic acids and bases as Uvasol ${ }^{\circledR}$ (Merck, Darmstadt), n-butanol (for chromatography, Riedel de Haen, Seelze near Hannover), Dowex $50 \mathrm{~W}-\mathrm{X} 8, \mathrm{H}^{+}$, mesh 200-400 (Serva, Heidelberg). Unless otherwise stated, all substances were dissolved in twice distilled water.

Heparin for biochemical research (180 I.U./mg)* (Hoffmann-La Roche, Grenzach)), $0.1 \mathrm{~N} \mathrm{NaOH}$ for titration of the gastric juice (Titrisol ${ }^{\circledR}$, Merck, Darmstadt), Tür's solution for leucocy te counts (acetic acid-gentian violet), May-Grunwald's solution (eosin-methylene blue) and Giemsa stain (azureosin-methylene blue) (Merck, Darmstadt).

\subsection{Test persons}

The investigations were carried out on 143 volunteers. The test persons had healthy case histories and in particular were devoid of allergic reactions, gastric diseases or complaints, and had normal pulse rate and blood pressure in sitting and prone positions, normal leucocy te counts and/or normal differential blood picture. The test persons consisted of 140 male and 2 female students and anesthetists between the ages of 22 and 31 years, weighing between 54 and $100 \mathrm{~kg}$;

\footnotetext{
* We thank Professor Dr. H. Gastpar, Munich, for supplying this substance.
} 
one test person (A. Doenicke) was himself one of the investigators in this paper.

\subsection{Sequence and arrangement of investigation}

The tests were conducted from 7 am to 9 an in a quiet well-lit room. The anaesthetic was administered during spontancous respiration. The test persons, on whom all investigative parameters were measured simultaneously. were handled in the following sequence and arrangement (fig. 1).

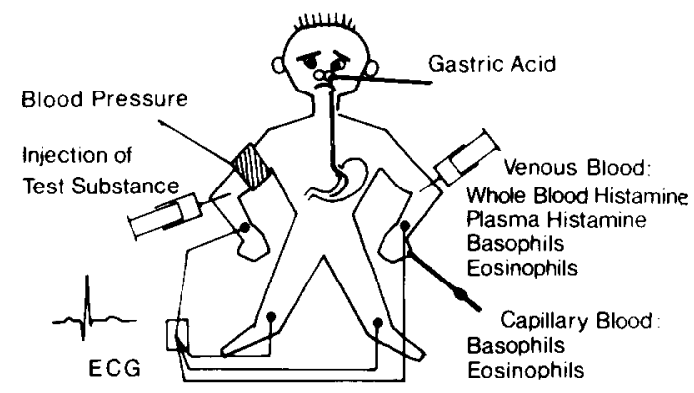

Fig. 1. Scheme of the arrangement of investigations in the test persons. Ior explanations see text under Materials anct Methods.

To begin with, a nasogastral tube with X-ray contrast strips (Levin No.12-14) was introduced in to the stomach, the position of which was radiologically controlled and, if necessary, corrected. After the tube was fixed on his nose, the test person laid down on a sofa with the upper body slightly raised. Leads for the ECG were attached to the extremities and a sphygmomanometer (Riva-Rocci) to measure blood pressure was fastened to the right upper arm. Then, in the right and left under-arms, polyethylene cannulae (Braunule ${ }^{\circledR}$. Braun. Melsungen) were inserted in to superficial veins, the right one being used for the injection of the anesthetic, solvent and other drugs, the left one being used for withdrawing blood for histamine assay in plasma and whole blood, as well as for leucocyte counts and blood smears. Capillary blood from the finger tips of the left hand was also used to determine leucocy te counts and the differential blood pictures.

If 1 or 2 of the parameters were not simultaneously measured, then the sequence of those still to be investigated remained, as stated above. To carry out this program, a very well-practiced team of at least
5 persons, including 2 anesthetists, was absolutely necessary.

When in any one of the investigations. a solvent and agent, or an agent at various conditions, were employed on one and the same test person, then the sequence of application of both solutions was alternated. Thus, when in one person Micellophor ${ }^{-\bar{k}}$ was used first and then Propanidid. in the next test person Propanidid was used first and then the solvent. The time lapse between the first and second investigation was always $2-4$ weeks.

The order as described above was also adhered to in studies with histamine infusion. Gastric acid secretion was not determined since the dose--effect relationship between histamine infusion and gastric acid secretion in humans is known from the literature (Hanson and Ivy. 1948; Adam et al., 1954; Lawrie et al., 1964; Lorenz and Pfleger, 1968).

The histamine solution was prepared using a sterilized stock solution from the University's pharmacy. diluting it with physiological saline. and then drawing it up into a $50-\mathrm{ml}$ polyethylene syringe. The histamine concentration of the fluid within the syringe was determined after the investigation by fluorometric assay. There was no loss of histamine caused by an adsorption on to the syringe surface.

I.v. infusions were given into the right arm using the infusion apparatus Unita II (Braun, Melsungen). while blood was withdrawn from a cubital vein of the left $\mathrm{arm}$, as in the other investigations. At the beginning, $0.9 \% \mathrm{NaCl}$ solution was infused, followed by the application of histamine from a separate syringe after which physiological saline was again in fused.

To avoid any side effects from infusion of the highest dose (headache, flush, etc.), the antihistaminic drug antazoline, $2 \mathrm{mg} / \mathrm{kg}$, was injected i.v. immediately prior to infusion.

\subsection{Determination of the various parameters}

2.4.1. Histamine assay in whole blood and plasma

From the left underarm, $5.0 \mathrm{ml}$ of blood were withdrawn with a polyethylene syringe $15 \mathrm{~min}$ before and immediately beforc, injection of the anesthetic or solvent, as well as at intervals of 3, 6, 10, 20 and $30 \mathrm{~min}$ after the i.v. application. The blood samples were put immediately into centrifuge tubes containing $5.0 \mathrm{ml} 1 \mathrm{~N} \mathrm{HClO}_{4}$ and centrifuged for $5 \mathrm{~min}$ at 
$1800 \mathrm{~g} .4 .0 \mathrm{ml}$ of the supernatant were stored for several days in a freezer at $-20^{\circ} \mathrm{C}$ and used later for histamine assay according to Lorenz et al. (1970a, 1971a) (Dowex method).

Immediately after the withdrawal of blood samples for whole blood histamine determination. $19.5 \mathrm{ml}$ of blood were withdrawn with a polyethylene syringe containing $2 \mathrm{mg}$ heparin dissolved in $0.5 \mathrm{ml}$ of $0.9 \% \mathrm{NaCl}$ solution and centrifuged immediately for $30 \mathrm{~min}$ at $1000 \mathrm{~g}$ and $1-2^{\circ} \mathrm{C} .6 .0 \mathrm{ml}$ of plasma were mixed with $2 \mathrm{ml}$ of $2 \mathrm{~N} \mathrm{HClO}_{4}$ and centrifuged for $10 \mathrm{~min}$ at $1800 \mathrm{~g}$. The whole supernatant was filtered through a filter paper and was either used immediately for histamine assay or stored in the freezer at $-20^{\circ} \mathrm{C}$, and histamine assayed several days later. Histamine was determined on a Zeiss spectrofluorometer ZFM 4 at a temperature of $21 \pm 0.5^{\circ} \mathrm{C}$ according to Lorenz et al. (1970a, 1972) (combined method).

Two types of blanks were used, in one $3 \mathrm{~N} \mathrm{HCl}$ was added to the mixture before the o-phtaldialdehyde solution (Shore et al., 1959, reversed blanks), in the other the plasma was substituted by fresh twice distilled water (histamine-free) and carried along throughout the procedure (reagent blanks). The high sensitivity of our method was partly due to strict control of the reagent blanks which should not be more than $10 \%$ higher than the reversed blanks (on the contrary see Van Redlich and Glick, 1965). On the other hand, the low concentration of o-phtaldialdehyde used in our method, $0.05 \%, w / v$, diminished both blanks considerably and thus increased the sensitivity of our assay.

\subsubsection{Determination of gastric acid secretion (Lorenz} et al., 1969; Lorenz, 1971).

After complete emptying of the stomach with a manually operated syringe, the nasogastral tube position was again tested by instillation of $20 \mathrm{ml}$ of $0.9 \%$ $\mathrm{NaCl}$ solution $\left(37^{\circ} \mathrm{C}\right)$ and reaspiration. Then basal secretion was collected by suction at intervals of $2 \mathrm{~min}$ over a period of $30 \mathrm{~min}$. When atropine had to be used, a dose of $0.01 \mathrm{mg} / \mathrm{kg}$ was administered i.v. 15 min after the beginning of the collection. At the end of the $30 \mathrm{~min}$, the anesthetic was injected and the gastric juice withdrawn by suction every min and collected in portions corresponding to the blood withdrawal, i.e., in 23 -min portions, 14 -min portion and 2 10-min portions. The volume of gastric juice was measured and the acid output determined for each portion by titration with $0.1 \mathrm{~N} \mathrm{NaOH}$ upto $\mathrm{pH} 7.0$ using a glass electrode. The acid output was given in mval HCl/min (Lorenz et al., 1969).

\subsubsection{Determination of heart rate and blood pressure}

The heart rate (beats/min) was determined from the average period length in lead II of the standard ECG (Heinecker, 1970). The arterial blood pressure (in $\mathrm{mm} \mathrm{Hg}$ ) was determined by indirect, sphygmanometric measurement (Riva-Rocci) according to the method of Burton (1965). Because the test persons were all young people (very little or no arteriosclerosis!), the blood pressure values obtained by the indirect method would have been similar to those ob. tained by a direct method. Indeed, the blood pressure values measured by indirect methods during anesthesia with propanidid agreed with those obtained by direct methods (Henschel and Buhr, 1965; Avrucki and Zinovjev, 1969; Soga and Beer, 1971).

2.4.4. Determination of basophil granulocyte content in peripheral venous and capillary blood

At the same time as the blood was withdrawn for histamine assay, 2 blood smears and 1 leucocyte count were made with venous and capillary blood. The leucocy te count was performed according to Von Müller et al. (1962), while the blood differential was determined according to Pappenheim, whereby 1000 cells from each sample were counted. The content of basophils in venous and capillary blood was determined according to Hamerston et al. (1956) (number of leucocytes $/ \mathrm{mm}^{3}$ and per cent of basophils in the blood smear). As the results of Moore and James (153) and Hamerston et al. (1956) have shown, the values from such an indirect method agree with those from a direct method. The content of basophils in the blood is given as the number of cells $/ \mathrm{mm}^{3}$.

\section{RESULTS}

\subsection{Plasma histamine levels during infusion of hista- mine and its correlation to heart rate and blood pres- sure}

With the highly sensitive histamine assay used in this study, an increase of plasma histamine concentration was measured after infusion of relatively low doses 

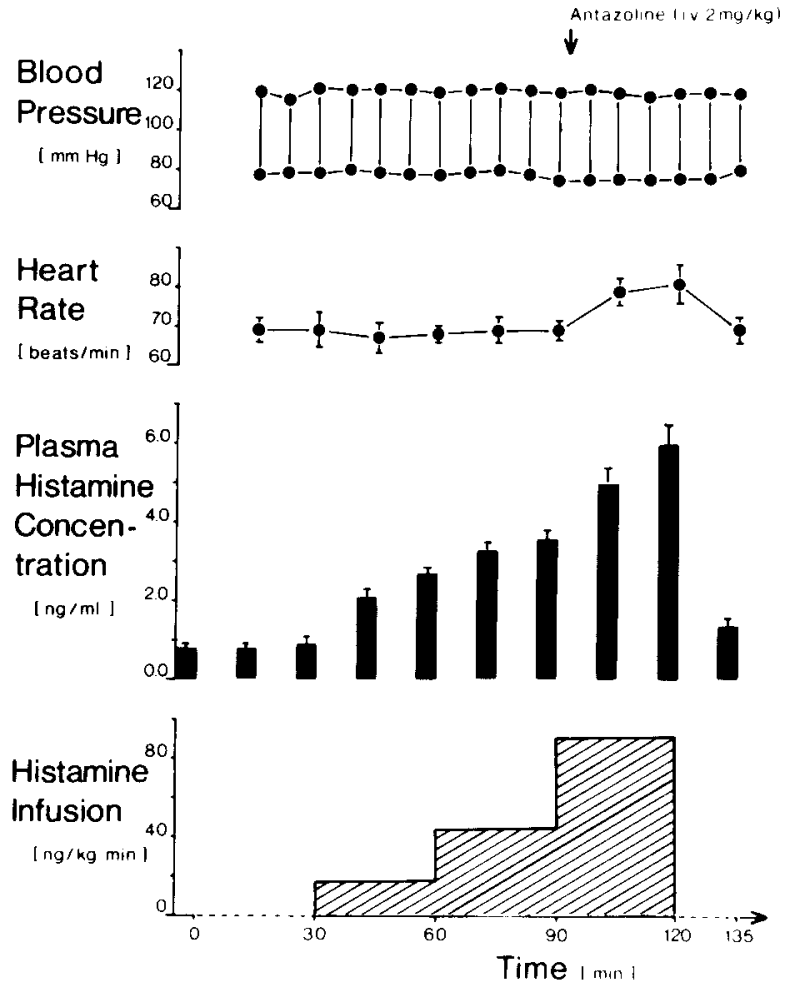

Fig. 2. Plasma histamine concentration, blood pressure and heart rate after intravenous infusion of increasing doses of histamine. Mean value \pm S.E.M., 3 probands were tested. For further conditions see Materials and Methods. of histamine, $(18 \ldots 90 \mathrm{ng} / \mathrm{kg}) / \mathrm{min}$. Furthermore, there was a relationship between the doses of histamine infused and the elevation of plasma histamine level (fig.2).

Doses of histamine up to $(45 \mathrm{ng} / \mathrm{kg}) / \mathrm{min}$ did not produce complaints or clinical symptoms in any of the 3 test persons. No effects on blood pressure or heart rate were observed, both relatively sensitive indicators of histamine release. Clinical reactions (a slight tachycardia and in one case only, also a slight headache) were observed after infusion of $(90 \mathrm{ng} / \mathrm{kg}) / \mathrm{min}$, despite antihistamine medication.

\subsection{Histamine release by propanidid and thiopentone \\ 3.2.1. Concentrations of plasma histamine after i.v. injection}

After i.v. administration of propanidid, in doses commonly used for anesthesia in man, the plasma histamine levels increased significantly to about $350 \%$ of the norm (table 1): the highest value was found 5 min after injection. The histamine concentration remained at an increased level even though anesthesia by propanidid had long since been ended. At least $30 \mathrm{~min}$ after the end of injection was required for histamine concentration to approximate to the initial levels (table 1). The i.v. administration of atropine did not significantly affect the concentration of plasma histamine, although this agent has been proven to

Table 1

Plasma histamine concentrations in man before and after the i.v. injection of propanidid, Micellophor ${ }^{(8)}$ and thiopentone. Mean values \pm S.D. With propanidid, $7 \mathrm{mg} / \mathrm{kg}$, i.v., injection time $20 \mathrm{sec}$, and Micellophor ${ }^{\circledR} 0.15 \mathrm{ml} / \mathrm{kg}$, i.v., injection time $20 \mathrm{sec}, 12$ male test persons were tested, with thiopentone, $5 \mathrm{mg} / \mathrm{kg}$, i.v., injection time $20 \mathrm{sec}, 8$ male probands were studied. Statistical significance was calculated between the values at zero time and those at several times after the injection. For further conditions see Materials and Methods.

\begin{tabular}{|c|c|c|c|c|c|c|}
\hline \multirow{2}{*}{$\begin{array}{l}\text { Time after } \\
\text { injection } \\
(\mathrm{min})\end{array}$} & \multicolumn{2}{|l|}{ Propanidid } & \multicolumn{2}{|l|}{ Micellophor ${ }^{\circledR}$} & \multicolumn{2}{|l|}{ Thiopentone } \\
\hline & $\begin{array}{l}\text { Histamine } \\
\text { content }(\mathrm{ng} / \mathrm{ml})\end{array}$ & $\begin{array}{l}\text { Signifi- } \\
\text { cance }\end{array}$ & $\begin{array}{l}\text { Histamine } \\
\text { content }(\mathrm{ng} / \mathrm{ml})\end{array}$ & $\begin{array}{l}\text { Signifi- } \\
\text { cance }\end{array}$ & $\begin{array}{l}\text { Histamine } \\
\text { content }(\mathrm{ng} / \mathrm{ml})\end{array}$ & $\begin{array}{l}\text { Signifi- } \\
\text { cance }\end{array}$ \\
\hline 0 & $0.85 \pm 0.33$ & - & $0.86 \pm 0.36$ & - & $0.80 \pm 0.32$ & \\
\hline 1 & $2.10 \pm 1.30$ & $p<0.005$ & $1.03 \pm 0.63$ & $p<0.4$ & - & - \\
\hline 3 & - & - & $0.88 \pm 0.50$ & - & $4.2 \pm 3.1$ & $p<0.01$ \\
\hline 5 & $3.80 \pm 2.10$ & $p<0.005$ & $0.92 \pm 0.58$ & - & - & $\cdots$ \\
\hline 6 & - & - & & & $2.9 \pm 1.3$ & $p<0.001$ \\
\hline 10 & $2.40 \pm 1.70$ & $p<0.01$ & $0.94 \pm 0.76$ & - & $2.0 \pm 0.9$ & $p<0.005$ \\
\hline 20 & $1.50 \pm 0.55$ & $p<0.005$ & $0.88 \pm 0.69$ & - & $1.6 \pm 0.64$ & $p<0.001$ \\
\hline 30 & $1.10 \pm 0.52$ & $p<0.2$ & $0.89 \pm 0.50$ & - & $1.0 \pm 0.48$ & $p<0.4$ \\
\hline
\end{tabular}


be a histamine liberator in humans, dogs and cats (Schachter, 1952; Rotschild, 1966).

For a long time, it has been assumed that the solvent of propanidid, Cremophor ${ }^{\circledR}$, or presently Micellophor $^{\oplus}$ released histamine in humans since they liberate histamine in $\operatorname{dogs}$ and cats (Lorenz et al., $1971 \mathrm{~b})$. In this study, the test persons who were treated with propanidid also received Cremophor ${ }^{(8)}$ and Micellophor ${ }^{\circledast}$ alone. The increase of plasma histamine concentration, about $20 \%$, was not statistically significant (table 1). Thus, it can be concluded that propanidid (anesthetic drug plus solvent), and not Cremophor $\left.{ }^{(}\right)$or Micellophor $\left.{ }^{(}\right)$, releases histamine in humans.

Thiopentone, in anaesthetic doses, also elevated plasma histamine concentration (table 1). The degree of elevation approximated that obtained after administration of propanidid; also the concentration of plasma histamine fell at approximately the same rate as after propanidid. The solvent used for thiopentone, $0.9 \% \mathrm{NaCl}$ solution did not lead to any increase of plasma histamine levels even when injected rapidly (see also fig.2).

3.2.2. Histamine concentrations and basophil contents in whole blood after injection of propanidid, Micellophor $\left.{ }^{(}\right)$and thiopentone

After i.v. injection of propanidid, the histamine concentrations and basophil contents of whole blood were not uniformly changed (fig. 3 ).

(a) In those cases where the basophil content remained constant, the histamine concentration increased significantly. However, this increase, approximately $30 \%$, did not agree with the increase of plasma histamine concentrations previously obtained, which was smaller than the $24 \mathrm{ng} / \mathrm{ml}$ observed in whole blood. It must therefore be assumed that histamine was briefly increased in compartments of the blood other than plasma ( mine in whole blood was already decreased after $30 \mathrm{~min}$.

(b) In those test persons in which whole-blood histamine concentration was not significantly changed, the number of basophils decreased significantly (fig.3). This could have been due to sequestration or partly also to degranulation of basophils. Ideally histamine assay and basophil count should be made on the same blood sample, because there was a

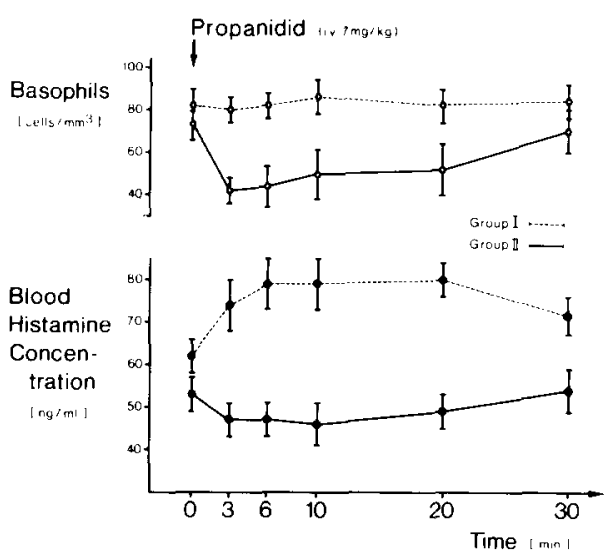

Fig. 3. Histamine concentration and basophil content in human whole blood: two kinds of reaction to propanidid. Mean values \pm S.E.M. 29 male probands were tested with propanidid, $7 \mathrm{mg} / \mathrm{kg}$, i.v., injection time $20 \mathrm{sec}$. They were divided into 2 groups which reacted to the anesthetic in a different manner: (1) 13 probands, who showed no more than $\pm 10 \%$ difference in their basophil content in blood at any time investigated after the injection of propanidid (o-- o). (2) 16 probands, who showed more than $\pm 10 \%$

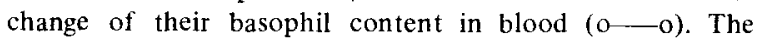
values at zero time were obtained from blood samples withdrawn immediately before the injection of propanidid. Statistical significance according to table 1 . Statistical significance: (o-- o) no significance; $0-0,0 / 3 p<0.02,0 / 6 p<0.05$, $0 / 10 p<0.1$; $\bullet--\bullet) 0 / 3 p<0.05,0 / 6 p<0.1,0 / 10 p<0.05$, $0 / 20 \quad p<0.02,0 / 30 \quad p<0.1$; $(\bullet \bullet)$ no significance. For further conditions see Materials and Methods.

large difference in the basophil content of venous and capillary blood; and no correlation between these values could be found ( $r=0.37, p<0.4, n=10)$.

The histamine concentration and the basophil content in whole blood remained unchanged after administering Cremophor ${ }^{\circledR}$ and Micellophor ${ }^{\circledR}$. After injection of thiopentone, there was a decrease of the basophil content in practically all cases (fig.4). The histamine concentration of whole blood remained unchanged, in accord with one of the test groups receiving propanidid ( see fig. 3 ).

3.2.3. Gastric acid secretion after i.v. administration of propanidid, Micellophor ${ }^{\circledR}$ and thiopentone

Rapid injection of propanidid resulted in approximately halfmaximal gastric acid secretion (table 2). The increased acid output parallel the increased plasma histamine concentration (fig.5); basal secretion was reached $30 \mathrm{~min}$ after injection. Micellophor ${ }^{\circledR}$ did 

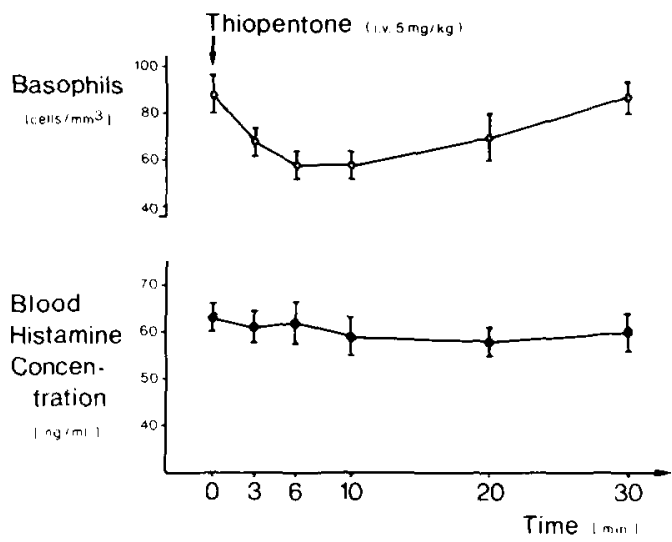

Iig.4. Histamine concentration and basophil content in human whole blood after injection of thiopentone. Mean values \pm S.E.M. 22 male probands were tested with thiopentone, $5 \mathrm{mg} / \mathrm{kg}$, i.v., injection time $20 \mathrm{sec}$. Atropine, $0.01 \mathrm{mg} / \mathrm{kg}$, i.v., was given as premedication $10 \mathrm{~min}$ before thiopentone. Zero time is defined as in fig. 3. Statistical significance according to table $1(\alpha-0), 0 / 3 p<0.1,0 / 6$ $p<0.02,0 / 10 p<0.05,0 / 20 p<0.2 ;(\bullet \bullet)$, no significance. For further conditions see Materials and Methods.

not significantly increase gastric secretion (table 2).

After an extremely rapid injection of propanidid (as used often in the past and referred to as 'one-shot injection'), gastric acid secretion was much more profuse than after a slower injection (table 2). Probably, slow injection of the drug resulted in less histamine being released, thus characterizing propanidid as a histamine liberator (Paton, 1956). This is somewhat surprising since propanidid is a neutral substance, whereas all other histamine liberators are basic conpounds. It is furthermore remarkable that with the very rapid injection the highest rate of gastric acid secretion was reached not less than 10 min after injection of the anesthetic (table 2).

The effect of histamine on gastric acid secretion is usually reduced, but not completely blocked, by atropine (Ivy and Bachrach, 1966). When propanidid was administered $10 \mathrm{~min}$ after injection of atropine, gastric secretion was reduced approximately $30 \%$ (table 2). Therefore the increase of histamine in human plasma after injection of propanidid represents an increase of free, pharmacologically active histamine.

Injection of thiopentone also stimulated gastric acid secretion in a similar manner to propanidid (table 3); for safety purposes, thiopentone was not ad-

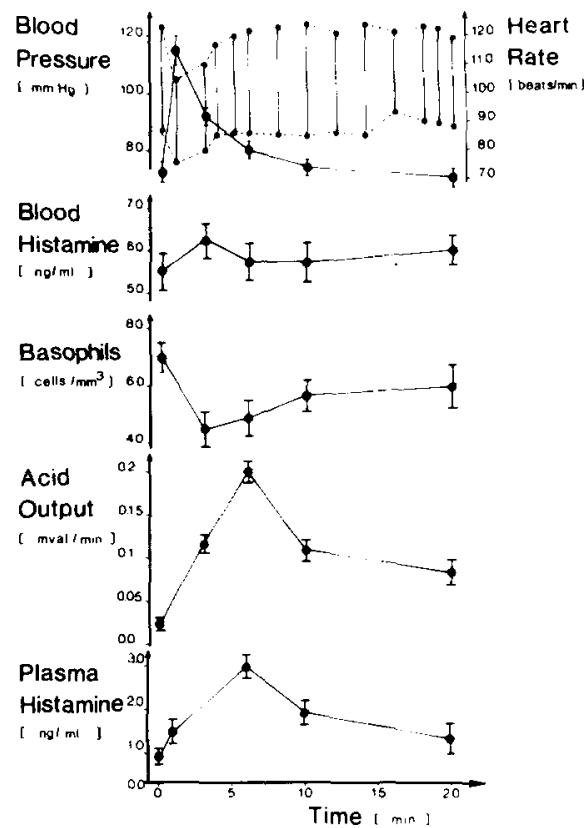

lig.5. Histamine concentration in whole blood and plasma, basophils, gastric acid secretion, blood pressure and heart rate after i.v. injection of propanidid. Mean values \pm S.E.M., 5 probands were tested after injection of propanidid, $7 \mathrm{mg} / \mathrm{kg}$, i.v., injection time $20 \mathrm{sec}$. In each test person all parameters were studied simultaneously. Heart rate..-blood pressure -... Blood pressure is given as systolicdiastolic pressure. For further conditions see Materials and Methods.

ministered without atropine premedication. I.v. injection of $10 \mathrm{ml}$ physiological saline, the solvent of thiopentone, did not stimulate gastric acid secretion.

3.2.4. Heart rate and blood pressure after injection of propanidid, Micellophor ${ }^{\circledR}$ and thiopentone

The heart rate was increased during the first $5 \mathrm{~min}$ after propanidid injection (fig.5). Systolic and diastolic blood pressure were significantly decreased during the first 2 min only that is, before the maximum increase in plasma histamine concentration (fig.5). Therefore, it is improbable that the initial tachycardia and the acute peripheral arterial hypotension are related to the release of histamine into the plasma. In contrast, stimulation of gastric acid secretion and decrease of basophils in the blood paralleled the increase of plasma histamine concentration (fig.5). The 
Table 2

Gastric acid secretion in man after injection of Micellophor ${ }^{\circledR}$ and propanidid at various conditions. Mean values \pm S.D. Propanidid, $7 \mathrm{mg} / \mathrm{kg}$, i.v., injection time $20 \mathrm{sec}$, if not otherwise stated. Micellophor ${ }^{\circledR}, 0.15 \mathrm{ml} / \mathrm{kg}$, i.v., injection time $20 \mathrm{sec}$. Atropine, $0.01 \mathrm{mg} / \mathrm{kg}$, j.v., $10 \mathrm{~min}$ before propanidid. Propanidid, slow means, an injection time of 40 - 50 sec; propanidid, rapid means, an injection time of $5-7 \mathrm{sec} . n=$ number of male probands tested, in each series of experiments the same test persons were investigated. The basal secretion before the injection of atropine (last column) was $0.016 \pm 0.019 \mathrm{mval} / \mathrm{min}$. Statistical significance was calculated as in table 1 , the $p$-values are added in parentheses. For further conditions see Materials and Methods.

\begin{tabular}{|c|c|c|c|c|c|c|}
\hline \multirow{3}{*}{$\begin{array}{l}\text { Time after } \\
\text { injection } \\
\text { (min) }\end{array}$} & \multicolumn{6}{|c|}{ Gastric acid output (mval/min) } \\
\hline & Propanidid & Micellophor $\left.{ }^{(}\right)$ & $\begin{array}{l}\text { Propanidid } \\
\text { (slow) }\end{array}$ & $\begin{array}{l}\text { Propanidid } \\
\text { (rapid) }\end{array}$ & Propanidid & $\begin{array}{l}\text { Propanidid } \\
+ \text { atropine }\end{array}$ \\
\hline & $n=9$ & $n=9$ & $n=11$ & $n=11$ & $n=9$ & $n=9$ \\
\hline 0 & $0.03 \pm 0.04$ & $0.04 \pm 0.05$ & $0.02 \pm 0.02$ & $0.02 \pm 0.02$ & $0.02 \pm 0.01$ & $0.01 \pm 0.01$ \\
\hline \multirow[t]{2}{*}{3} & $0.28 \pm 0.28$ & $0.09 \pm 0.12$ & $0.13 \pm 0.12$ & $0.14 \pm 0.12$ & $0.32 \pm 0.29$ & $0.15 \pm 0.16$ \\
\hline & $(p<0.02)$ & $(p<0.3)$ & $(p<0.005)$ & $(p<0.005)$ & $(p<0.01)$ & $(p<0.025)$ \\
\hline \multirow[t]{2}{*}{6} & $0.25 \pm 0.21$ & $0.09 \pm 0.10$ & $0.09 \pm 0.11$ & $0.18 \pm 0.23$ & $0.26 \pm 0.21$ & $0.20 \pm 0.23$ \\
\hline & $(p<0.01)$ & $(p<0.3)$ & $(p<0.05)$ & $(p<0.05)$ & $(p<0.005)$ & $(p<0.025)$ \\
\hline \multirow[t]{2}{*}{10} & $0.20 \pm 0.17$ & $0.08 \pm 0.08$ & $0.10 \pm 0.13$ & $0.25 \pm 0.24$ & $0.14 \pm 0.10$ & $0.11 \pm 0.13$ \\
\hline & $(p<0.02)$ & $(p<0.3)$ & $(p<0.1)$ & $(p<0.005)$ & $(p<0.005)$ & $(p<0.05)$ \\
\hline \multirow[t]{2}{*}{20} & $0.10 \pm 0.09$ & $0.07 \pm 0.08$ & $0.07 \pm 0.11$ & $0.12 \pm 0.11$ & $0.09 \pm 0.10$ & $0.10 \pm 0.11$ \\
\hline & $(p<0.1)$ & $(-)$ & $(p<0.1)$ & $(p<0.02)$ & $(p<0.05)$ & $(p<0.05)$ \\
\hline \multirow[t]{2}{*}{30} & $0.05 \pm 0.07$ & $0.03 \pm 0.04$ & $0.03 \pm 0.03$ & $0.07 \pm 0.09$ & $0.03 \pm 0.04$ & $0.05 \pm 0.06$ \\
\hline & $(-)$ & $(-)$ & $(--)$ & $(-)$ & $(-)$ & $(p<0.05)$ \\
\hline
\end{tabular}

Table 3

Gastric acid secretion in man after injection of thiopentone. Mean values \pm S.D. Thiopentone, $5 \mathrm{mg} / \mathrm{kg}$, i.v., injection $20 \mathrm{sec}$. Atropine, $0.01 \mathrm{mg} / \mathrm{kg}$, i.v., $10 \mathrm{~min}$ before thiopentone. Basal secretion before atropine $0.021 \pm 0.015$ (mval/ min). 13 male probands were tested. Statistical significance was calculated as in table 1 . For further conditions see Materials and Methods.

\begin{tabular}{lll}
\hline $\begin{array}{l}\text { Time after } \\
\text { injection } \\
(\mathrm{min})\end{array}$ & $\begin{array}{l}\text { Gastric acid } \\
\text { output } \\
\text { (mval/min) }\end{array}$ & Significance \\
\hline 0 & $0.01 \pm 0.01$ & - \\
3 & $0.11 \pm 0.01$ & $p<0.001$ \\
6 & $0.19 \pm 0.13$ & $p<0.001$ \\
10 & $0.13 \pm 0.12$ & $p<0.005$ \\
20 & $0.05 \pm 0.09$ & $p<0.1$ \\
30 & $0.04 \pm 0.09$ & $p<0.1$ \\
60 & $0.02 \pm 0.02$ & $p<0.3$ \\
\hline
\end{tabular}

highest plasma histamine concentration reached, $3.1 \mathrm{ng} / \mathrm{ml}$, would not have been expected from the results of histamine infusion studies (fig.2), to produce tachycardia or hypotension.

After injection of Micellophor ${ }^{(\circledast)}$, there was no change in heart rate or blood pressure.
Following thiopentone injection, there was a slight and shortlasting increase in heart rate and a slight, but significant, hypotension (fig.6); as with propanidid, these changes occurred before the maximum increase in plasma histamine concentration. Stimulation of gastric acid secretion and the decrease of basophils in the blood parallel the increase of plasma histamine (fig.6). Therefore, and as with propanidid, there was no correlation between the changes of heart rate and blood pressure and the release of histamine into the plasma; circulatory changes due to released histamine were not expected from a plasma histamine concentration of $3.2 \mathrm{ng} / \mathrm{ml}$.

\section{DISCUSSION}

Determination of histamine in blood plasma is a prerequisite for the demonstration of histamine release in man by anesthetics. To date no successful methods existed for measuring such low increases of plasma histamine concentration. Furthermore, the earlier methods were not specific for histamine (Lorenz et al., 1972). 


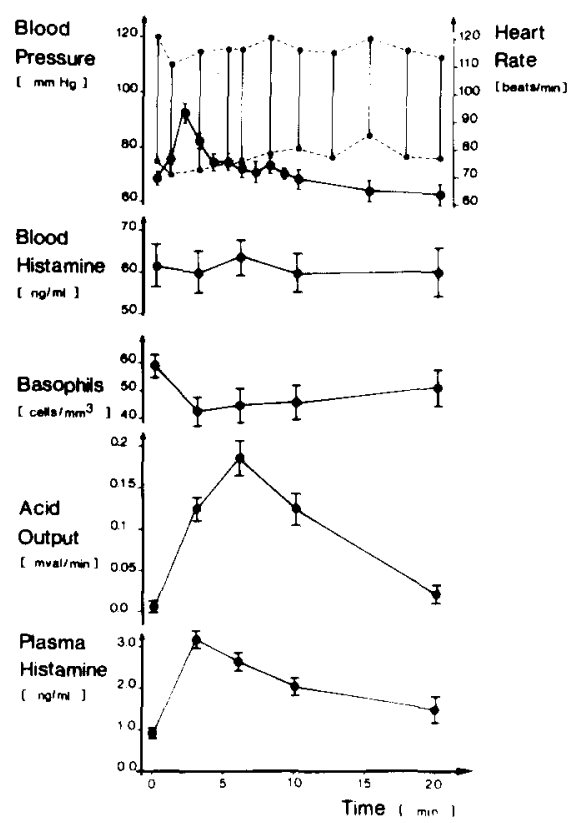

Fig.6. Histamine concentration in whole blood and plasma, basophils, gastric acid secretion, blood pressure and heart rate after i.v. injection of thiopentone. Mean values \pm S.E.M., 5 probands were tested after the injection of thiopentone, $5 \mathrm{mg} / \mathrm{kg}$, i.v., injection time $20 \mathrm{sec}$. In each person all parameters were studied simultaneously. Heart rate, $\bullet-\bullet$, blood pressure $\bullet-\cdots$. For further conditions see Materials and Methods.

Only the methods of Adam et al. (1957) and Graham et al. (1968) produced results in agreement with our values (Lorenz et al., 1970a, b, c; Doenicke and Lorenz, 1970). The 'histamine values' found by the other authors, over a period of more than 30 years (for a survey see Lorenz et al., 1972), were either up to 100 times too high or were below the limit of sensitivity of the method (e.g. below $3 \mathrm{ng} / \mathrm{ml}$ ). The high 'histamine values' were due to substances fluorescing after condensation with o-phthaldialdehyde which were not, or not sufficiently, separated from histamine during the purification procedure (Lorenz et al., 1970a). The less than satisfactory methods used in previous investigations makes necessary revision of all results on histamine release in humans which are based upon plasma histamine assay.

Determination of histamine in human blood as a measure of histamine release is afflicted with a num- ber of problems. As Paton (1957) has already remarked, the determination must include a determination of the content of the corpuscular elements in the blood to be assured that their contents have not altered. Since histamine in human blood is almost exclusively located in the basophil granulocytes (Graham et al., 1955; Lorenz et al., 1972), histamine concentration in whole blood is dependent on the absolute density of these cells in the blood. The density of these cells was altered in approximately $50 \%$ of cases after propanidid and in almost all cases after thiopentone.

In those test persones receiving propanidid and with a constant blood basophil content, the histamine concentration in whole blood increased to approximately $24 \mathrm{ng} / \mathrm{ml}$, whereas the plasma histamine level only increased to approximately $3 \mathrm{ng} / \mathrm{ml}$. Thus, the increase of histamine in whole blood did not correspond to the increase in plasma histamine, and above all, the histamine was not pharmacologically active, as shown by the results of the infusion experiments (fig.2). A facultative, short-term uptake in eosinophil granulocytes and erythrocytes should be considered (Code et al., 1964; Lindell and Viske; 1961; Lorenz and Werle, 1971). The eosinophil content increased in propanidid and thiopentone narcosis (Lorenz and Doenicke, unpublished). However, it is not known if the eosinophils store so much histamine under our experimental conditions.

The big difference between plasma and whole blood histamine levels in humans (relationship approx. $1: 100$ ) is the reason why only large increases of plasma histamine, as seen in severe incidents (Lorenz et al., 1972a), can dependably be measured by histamine determination in whole blood, and then only when the basophil content remains constant. However, since the histamine increase in whole blood is not entirely free histamine, the determination of this amine in human whole blood as a method for determining histamine release by anesthetics and muscle relaxants (Westgate and van Bergen, 1962; Lorenz et al., 1969; Doenicke and Lorenz, 1970), is of limited value and should be combined with indirect measures such as gastric secretion, heart or pulse rate and blood pressure.

Indirect methods for the determination of histamine release are not specific. Therefore, several of the following measurements should be included to en- 
hance specificity of the assay: determination of blood pressure decrease in peripheral circulation, the socalled 'delayed depressor response' (McIntosh and Paton, 1949); tachycardia; hemoconcentration; gastric secretion; increase of bronchial resistance upto bronchospasm; erythema, edema (skin tests), etc. The prevention of clinical symptoms by antihistaminics is also an indirect method of proving histamine release although specificity of antihistaminics is much less than is normally assumed (Werle and Lorenz, 1970). In the future, all indirect methods should be combined with a determination of plasma histamine. The value of such a combined procedure lies above all in demonstrating the pharmacological and pathophysiological effectiveness of histamine released into the plasma. The results permit the following conclusions relating to histamine release by propanidid and thio. pentone: (1) in normal persons, i.v. injections of both anesthetics release histamine in to the plasma, in quantities sufficient to stimulate gastric acid secretion, but not to produce reactions in the circulatory system; increase of heart rate is one of the most sensitive reactions of the circulatory system to histamine (Lecomte, 1956); (2) in normal persons, the changes in the circulatory system, e.g. tachycardia and hypotension, observed in the first minutes after injection of both anesthetics, cannot be attributed to a release of histamine into the plasma (Lorenz et al.. 1972a). However, release of histamine from the heart cannot be excluded as a cause of these reactions and this aspect must be separately studied; (3) in persons with abnormalities relating to histamine storage or catabolism, as well as in those with an 'allergic diathesis', release of large amounts of histamine by propanidid or thiopentone, sufficient to evoke strong reactions from the circulatory system cannot be excluded. Such incidents with propanidid are described in another paper (Lorenz et al., 1972a).

\section{REFERENCES}

Adam, H.M., W.J. Card, M.J. Riddell, M. Roberts and J.A. Strong, 1954, The effect of intravenous infusions of histamine on the urinary histamine and on gastric secretion in man, Brit. J. Pharmacol. 9, 54.

Adam, H.M., O.C. Hardwick and K.E.V. Spencer, 1957, Method for determination of histamine in plasma, Brit. J. Pharmacol. 12, 397.
Alam, M.. G.V. Anrep, G.S. Barsoum, M. Talaat and E. Wieninger, 1939. Liberation of histamine from the skeletal muscle by curare, J. Physiol. (London) 95, 148.

Avrucki, M.J. and E.S. Zinovjev, 1969, Symposium on propanidid, Moscow, 5-6 June (Bayer, Leverkusen) p. 50.

Burton, A.C., 1965, Physiology and biophysics of the circulation, German edition, 1969 (F.K. Schattauer, Stuttgart) p. 178 .

Code, C.F., 1952, Histamine in blood, Physiol. Rev. 32, 47.

Code, C.F., M.M. Hurn and R.G. Mitchell, 1964, Histamine in human disease, Mayo Clin. Proc. 39, 715

Doenicke, A. and W. Lorenz, 1970. Histaminfreisetzung und anaphylaktoide Reaktionen bei i.v. Narkosen, Anaesthesist 19,413 .

Doenicke, A., J. Krumey, J. Kugler and J. Klempa, 1968 , Experimental studies of the breakdown of epontol: determination of propanidid in human serum. Brit. J. Anaesth. 40,415 .

Graham, H.T., O.H. Lowry, F. Wheelwright, M.A. Lenz and H.H.Parish, Jr., 1955, Distribution of histamine among leucocy tes and platelets, Blood 10,467.

Graham, H.T., J.A.D. Scarpellini, B.P. Hubka and D.H. Lowry, 1968, Measurement and normal range of free histamine in human blood plasma, Biochem. Pharmacol. 17 , 2271 .

Hamerston, D., L. Elvebach, F. Halberg and R.J. Gully, 1956, Correlation of absolute basophil and eosinophil counts in blood from institutionalized human subjects, J. Appl. Physiol. 9, 205.

Hanson, M.E. and A.C. Ivy, 1948, Histamine and gastric secretion, Amer. J. Physiol. 153, 242.

Heinecker, R., 1970, EKG - Fibel (Georg Thieme, Stuttgart) p. 27.

Henschel, W.F. and G. Buhr, 1965, Kreislaufuntersuchungen während der Propanidid-Kurznarkose. Anesthesiology and Resuscitation, 4 (Springer, Heidelberg, Berlin. New York) p. 227 .

Ivy, A.C. and W.II. Bachrach, 1966, Physiological significance of the effect of histamine on gastric secretion, in: Handbook Expt1. Pharmacol, Vol.18/1 (Springer, Heidelberg, Berlin, New York) p.810.

Lawrie, J.H., G.M.P. Smith and A.P.M. Forrest, 1964, The histamine-jnfusion test, Lancet ii., 270.

Lecomte, J., 1956, Endogenous histamine liberation in man, in: Ciba Found. Symp. on Histamine (I. and A. Churchill, London) p. 173.

Lindell, S.E. and K. Viske, 1961, A note on the distribution of ${ }^{14} \mathrm{C}$-histamine added to blood, Brit. J. Pharmacol. 17, 131.

Lorenz, W., 1971, Klinisch-Chemische Magenfunktionsdiagnostik. I. Bestimmung der Sekretionskapazität des Magens mit Hilfe des maximalen Betazol- oder Pentagastrin-testes, Klin. Chem. Mitt. 1, 1.

Lorenz, W. and K. Pfleger, 1 968, Stoffwechsel und physiologische Funktion von Histamin im Magen, Klin. Wschr. 46, 57.

Lorenz, W. and E. Werle, 1971, Occurrence, distribution and 
subcellular localization of histamine in man, animals and plants, in: Intern. Encycl. Pharmacol. Therap. Section 74 (Pereamon Press, Oxford) (in press).

Lorenz, W., A. Doenicke, S. Italbach. I. Krumey and E. Werle. 1969. Histaminfreisetzung und Magensaftsekretion bei Narkosen mit Propanidid (Epontol $\left.{ }^{\circledR}\right)$, Klin. Wschr. 47. 154.

Lorenz, W., L. Benesch, H. Barth. I: Matejka, R. Meyer. J. Kusche, M. Hutzel and F. Werle, 1970a. Fluorometric assay of histamine in tissues and body thuids: Choice of the purification procedure and identification in the nanogram range, Z. Anal. Chem. 252, 94.

Lorenz, W.. G. Fivel. A. Schmal. M. Hutzel and F. Werle. 1970b, Zum Mechanismus der Sekretionsstimulierung und Blutdrucksenkung durch Histalog $\left\{\right.$ Betazol ${ }^{(\uplus)}$ ): Histaminlibericrung und Potenzicung der Wirkung von Kininen und Serotonin.

Lorenz. W.. A. Doenithe. G. Leifel. K. Messmer, R. Meyer, L.. Benesch. II, Barth, J. Kusche, N1. Hutzel and I: Werle. 19706. Histamine release in man by propanidid (Epontol ${ }^{(b)}$ ). gelatine (Hacmaccel ${ }^{(B)}$ ), histalog, pentagastrin and insulin, Naunyn-Schmicdebergs Arch. Pharmakol. 266. 396.

Lorenz. W., H. Barth, J. Kusche, H.J. Rcimann, A. Schmal, 1. Matejka, Ch. Mathias, M. Hutzel and E. Werle, $1971 \mathrm{a}$, llistamine in the pig: determination. distribution, release and pharmacological actions. European J. Pharmacol. 14, 155 .

lorenz. W., R. Meyer. A. Doenicke, A. Schmal. HIJ. Reimann. M. Hutel and 1. Werle, 1971h. On the species specificity of the histamine release from mast cell stores by cremophor-li, Naunyn-Schmicdeberes Arch. Pharmakol. 169,417.

Lorenz, W. A. Doenicke, R. Meyer, II.J. Remann, J. Kusche, H. Barth, H. Geesing, M. Hutzel and B. Weissenbalcher, 1972a. Histamine release by propanidid and thiopentone: Pharmacological effects and clinical consequences. Brit. I. Anaesth. 44, 355 .

Lorenz. W., H.J. Reimann. II. Barth, J. Kusche, R. Meyer, A. Doenicke and M. Hutzel, 1972, A sensitive and specific method for the determination of histamine in human whole blood and plasma. 2. Physiol. Chem. (in press).

MacIntosh. I.C. and W.1.M. Paton, 1949, The liberation of histamine by ertain organic bases. J. Physiol. (London) 109.190

Moore, J.I. and G.W. James 1953. A simple direct method for absolute basophil leucocyte count. Pros. Soc. Fisptl. Biol. Med. 83,601.

Murphey, P., 1962. Histamine in anesthesia, Brit. J. Anatsth. 34,397

Paton, W.D.M., 1956. The mechanism of histamine release. in: Ciba lound. Symp. on llistamine (I. and $A$. Churchill. London) p.59.

Paton, W.D.M., 1957, Ilistamine release by compounds of simple chemical structure. Pharmacol. Rev. 9. 269.

Paton. W.D.M. 1959. The effects of muscle relaxants other than muscular relaxation. Anesthesiology 20,453.

Rothschild. A.M1. 1966. Histamine refease by basic compounds, in: landbook lisptl. Pharmacol. Vol.l8/1 (Springer, Ileidelberg. Berlin, New York) p.386.

Schachter, M., 1952. The release of histamine by pethidine. atropine, quinine, and other drugs, Brit. J. Pharmacol. 7. 646.

Scholtan, W, and Su Yung Lic, 1966. Kolloid-chenische kigenschaften eines neuen kurznarkotikums. Armeimittel-Forsch. 16,679.

Shore. P.A., A. Burkhalter and V.H. cohn Jr.. 1959, A method for the fluorometric assay of histamine in tissues. J. Pharmacol. Exptl. Therap. 127, 182.

Soga, D. and A. Beer, 1971, personal communication.

Von Müller. I., O. Seifert and II. Van Kress, 1962. Taschenbuch der medizinisch-klinischen Diagnostik (1.1. Bergmann. Munchen) p.453.

Von Redich. D. and D. Glick, 1965. Studies in histochemistry. LXXVI lluorometric determination of histamine in microgram samples of tissue or microliter volumes of body fluids, Anal. Biochem. 10, 459.

Werle, E. and W. Lorenz, 1970. The antikinin action of some antihistaminic drugs on the isolated guinea-piz ileum, rat uterus and blood pressure of the anesthetized dog, in: Bradykinin and Related Kinins. Advan. Lxptl. Biol. Med., Vol.8 (Plenum Press. New York) p.447.

Westgate. 11. and 1:11. Van Bergen. 1962. (hanges in histamine blood levels following d-tubocurarine administradion. Citn. Anacsth. Soc. J. 9,497.

Wirth, W. and I: Hoftmeister, 1965. Pharmakologische Untersuchungen mit Propanidid. Anaesth. Wiederbel. 4. 17. 